\title{
SPECTROSCOPIC STUDIES ON POUZOLZIA WIGHTII BENN
}

\section{Original Article}

\author{
SYED ALI FATHIMA M., JOHNSON M.*
}

Centre for Plant Biotechnology, Research Department of Botany, St. Xavier's College (Autonomous), Palayamkottai, Tamil Nadu, India

Email: ptcjohnson@gmail.com

Received: 21 Apr 2017 Revised and Accepted: 01 Feb 2018

\begin{abstract}
Objective: The present study was aimed to reveal the spectroscopic profile (UV-Vis and FT-IR) of Pouzolzia wightii Benn.

Methods: To detect the UV-Vis spectroscopic profile of $P$. wightii crude extracts were examined under UV-Vis Shimadzu spectrophotometer with the wavelength ranged from 100 to $1100 \mathrm{~nm}$. About $1 \mathrm{mg}$ of different extracts of petroleum ether, chloroform, ethyl acetate and acetone, ethanolic extracts of $P$. wightii were separately made into thin discs with 10-100 mg of potassium bromide using a mould and pressed under anhydrous conditions. The pellets were measured in an automatic recording FT-IR Spectrophotometer (Shimadzu $8400 \mathrm{~S}$ ) in the range of 400 to $4000 \mathrm{~cm}^{-1}$

Results: In UV-Vis analysis, $P$. wightii petroleum ether extracts showed more number of peaks in roots (15) than other studied parts. Chloroform and ethyl acetate extracts of $P$. wightii leaves observed 9 peaks and acetone extracts of $P$. wightii stem showed 10 peaks. Medicinal property of plant extracts are confirmed by the presence of secondary metabolites. FT-IR analysis of ethyl acetate extracts of $P$. wightii leaves, stem and root observed the highest number of $(16,12$ and 16$)$ functional compounds.

Conclusion: These UV-Vis and FT-IR spectroscopic results may be used as a pharmacognostic marker in the pharmaceutical industries and can be used as a chemometric tool to distinguish the studied $P$. wightii leaves, stem and root. The present study used to find out the bioactive compounds which may be subjected to subsequent target isolation. Further research will be needed for the structural characterization of the isolated compound by the use of different analytical methods such as NMR and mass spectrophotometer.
\end{abstract}

Keywords: Pouzolzia wightii, FT-IR-Fourier Transform-Infra Red, UV-Vis-Ultra Violet-Visible, Pharmacognosy

(C) 2018 The Authors. Published by Innovare Academic Sciences Pvt Ltd. This is an open-access article under the CC BY license (http://creativecommons.org/licenses/by/4.0/) DOI: http://dx.doi.org/10.22159/ijpps.2018v10i3.19336

\section{INTRODUCTION}

Medicinal plants are abundantly available all over the world and are gaining a lot of attention due to their specific role in various health care of human immune system in different nations. They serve as therapeutic agents as well as important raw materials for the manufacture of traditional and modern medicine [1]. Plant-based drugs are highly effective, low cost, easily available, evidently minor toxicity as side effects and proving to be a good substitute for allopathic medicines [2]. Phytochemicals are biologically active chemical compounds naturally present in a plant which acts as a natural defence system for plants and provide aroma, colour and flavour. They have a significant role in treating human diseases such as cancer, coronary heart diseases, diabetes and infectious diseases [3]. The therapeutic properties of medicinal plants are due to some phytochemical compounds. Various secondary metabolites with different Biopotency were present in medicinal plants which include flavonoids, carotenoids, alkaloids, anthocyanidins, phenolics, tannins, carboxylic acids, terpenoids, amino acids and inorganic acids [4]. Presence of these phytoconstituents provides specific distinctiveness and properties to the plants [5]. Therefore, the phytochemical analysis of these constituents would help in determining various biological activities of plants. A variety of techniques can be used to determine the presence of such phytoconstituents in medicinal plants. Spectroscopic (FT-IR-Fourier Transform-Infra Red; UV-Vis-Ultra Violet-Visible) methods together or separate can be used in this sense as well as conventional methods [6]. In many applications other techniques are available but UV-Visible spectrometry is specifically used for its simplicity, versatility, speed, accuracy and cost-effectiveness; it is used to determine the chemical compounds of the plants.

UV-Vis spectrophotometry related to the spectroscopy of photons in the UV-visible region. UV-Visible spectroscopy uses light in the visible ranges or its adjacent ranges. FT-IR is a measurement technique to identify the functional constituents and concrete structure of certain plant secondary metabolites [7, 8]. In chemotaxonomy and pharmacognosy, the UV-Vis and FT-IR spectroscopic profiles are used as a biochemical and pharmacognostical marker to identify the medicinal source. But there is no report on the spectroscopic studies of Pouzolzia wightii Benn. With this background, the present study was aimed to reveal the spectroscopic profile (UV-Vis and FT-IR) of Pouzolzia wightii Benn.

\section{MATERIALS AND METHODS}

\section{Preparation of extracts}

Pouzolzia wightii Benn was collected from their natural habitats and thoroughly washed by using tap water and then followed by distilled water to remove the unwanted debris. To remove the excess water, plant samples were blotted on the blotting paper and shade dried at room temperature for $20 \mathrm{~d}$. The shade dried samples were grounded to a fine powder using a mechanical grinder. The powdered samples were stored in airtight container. The powdered materials $(30 \mathrm{~g})$ of $P$. wightii were successively extracted with $400 \mathrm{ml}$ of petroleum ether, chloroform, ethyl acetate, acetone and ethanol (Hi-Media, Mumbai) using Soxhlet extractor for 8-12 $\mathrm{h}$ at a temperature not exceeding the boiling point of the solvents. The residues of the plant samples were obtained and stored in a refrigerator at $4^{\circ} \mathrm{C}$ for further studies.

\section{Chemicals and reagents}

The solvents used in this study are purchased from Hi-Media, Mumbai, India.

\section{UV-Vis analysis}

UV-Vis spectrophotometer analysis, the extracts were centrifuged at $3000 \mathrm{rpm}$ for $10 \mathrm{~min}$ and filtered through Whatmann No. 1 filter paper and the filtrate was used for spectroscopic analysis. To detect the UV-Vis spectroscopic profile of $P$. wightii crude extracts were examined under UV-Vis shimazdu spectrophotometer with the wavelength ranged from 100 to $1100 \mathrm{~nm}$. 


\section{FT-IR spectroscopic analysis}

FT-IR analysis was performed using Perkin Elmer Spectrophotometer system, which was used to detect the characteristic peaks and their functional groups. About $1 \mathrm{mg}$ of different extracts of petroleum ether, chloroform, ethyl acetate and acetone, ethanolic extracts of $P$. wightii were separately made into thin discs with 10 $100 \mathrm{mg}$ of potassium bromide using a mould and pressed under anhydrous conditions.

The pellets were measured in an automatic recording FT-IR Spectrophotometer (Shimadzu 8400S) in the range of 400 to 4000 $\mathrm{cm}^{-1}$. The percentage of transmissions was recorded against the wave number. The peak values of FT-IR were recorded and the functional groups were predicted [9]. Each and every analysis was repeated twice for the spectrum confirmation.

\section{RESULTS}

\section{UV-Vis analysis}

The UV-Vis spectroscopic profile of different extracts of $P$. wightii were taken from wavelength ranged from 200 to $800 \mathrm{~nm}$ due to the sharpness of the peak values and proper baseline. The presence of an absorbance band at a particular wavelength is a good indicator for the presence of a chromophore. The absorbance of the extracts revealed the concentrations of compounds present in the crude extracts. These spectrum profiles are useful to identify the specific bioactive classes of compounds found in various extracts of $P$. wightii.
The results of UV-Vis spectroscopic analysis of petroleum ether, chloroform, ethyl acetate, acetone and ethanol extracts of $P$. wightii leaves, stem and roots were illustrated in table 1. UV-Vis spectroscopic profile of ethanol, chloroform, ethyl acetate extracts of $P$. wightii leaves displayed more number of peaks (5) followed by acetone ( 3 peaks) and petroleum ether extracts ( 2 peaks). In $P$. wightii leaves, UV region showed only one peak with 0.325 absorbances at $319 \mathrm{~nm}$. The invisible region, ethyl acetate extracts of $P$. wightii leaves represented the maximum absorbance 4.000 at $403 \mathrm{~nm}$ and petroleum ether extracts of $P$. wightii leaves were illustrated minimum absorbance 0.062 at $668 \mathrm{~nm}$ in table 1 .

In $P$. wightii stem, acetone and ethyl acetate extracts expressed more number of peaks (6) followed by ethanol and chloroform (4), petroleum ether (3) extracts. Acetone extracts of $P$. wightii stem showed the highest absorbance 3.457 at $339 \mathrm{~nm}$ and the lowest absorbance 1.931 at $305 \mathrm{~nm}$ in UV region. The invisible region, chloroform extracts showed the maximum absorbance 2.436 at $665 \mathrm{~nm}$ and petroleum ether extracts illustrated minimum absorbance at $666 \mathrm{~nm}$ (table 1).

Among the five different extracts of $P$. wightii root, chloroform and petroleum ether extracts expressed more number of peaks (7) followed by ethanol and ethyl acetate ( 6 peaks), acetone (1 peaks) extracts. An ethyl acetate extracts of $P$. wightii root exhibited highest absorbance 1.702 at $307 \mathrm{~nm}$ and the lowest absorbance 0.317 at $319 \mathrm{~nm}$ in petroleum ether extracts. Invisible region, acetone extract represented the maximum absorbance 1.011 at $661 \mathrm{~nm}$ and petroleum ether extracts exhibited minimum absorbance 0.118 at $533 \mathrm{~nm}$ (table 1).

Table 1: UV-Vis peak values of Pouzolzia wightii

\begin{tabular}{|c|c|c|c|c|c|c|}
\hline \multirow[t]{2}{*}{ Plant extracts } & \multicolumn{2}{|l|}{ Leaves } & \multicolumn{2}{|l|}{ Stems } & \multicolumn{2}{|l|}{ Roots } \\
\hline & $\lambda \max$ & ABS & $\lambda \max$ & ABS & $\lambda \max$ & ABS \\
\hline \multirow[t]{7}{*}{ Petroleum ether } & 668 & 0.062 & 751 & 0.03 & 791 & 0.082 \\
\hline & 319 & 0.325 & 666 & 0.063 & 667 & 0.145 \\
\hline & & & 310 & 2.962 & 607 & 0.111 \\
\hline & & & & & 533 & 0.118 \\
\hline & & & & & 505 & 0.124 \\
\hline & & & & & 409 & 0.263 \\
\hline & & & & & 319 & 0.317 \\
\hline \multirow[t]{6}{*}{ Ethanol } & 666 & 0.462 & 665 & 0.15 & 664 & 0.237 \\
\hline & 608 & 0.122 & 497 & 0.182 & 606 & 0.169 \\
\hline & 531 & 0.178 & 402 & 0.512 & 538 & 0.189 \\
\hline & 502 & 0.219 & 305 & 1.931 & 504 & 0.202 \\
\hline & 402 & 2.128 & & & 407 & 0.547 \\
\hline & & & & & 307 & 1.557 \\
\hline \multirow[t]{6}{*}{ Ethyl acetate } & 664 & 1.311 & 664 & 0.381 & 665 & 0.236 \\
\hline & 606 & 0.399 & 604 & 0.201 & 605 & 0.128 \\
\hline & 540 & 0.559 & 534 & 0.268 & 536 & 0.153 \\
\hline & 504 & 0.614 & 502 & 0.308 & 504 & 0.167 \\
\hline & 403 & 4 & 409 & 1.216 & 409 & 0.671 \\
\hline & & & 307 & 2.991 & 307 & 1.702 \\
\hline \multirow[t]{7}{*}{ Chloroform } & 697 & 0.889 & 953 & 1.26 & 699 & 0.189 \\
\hline & 667 & 1.487 & 665 & 2.436 & 666 & 0.261 \\
\hline & 609 & 0.719 & 606 & 1.959 & 608 & 0.208 \\
\hline & 544 & 0.899 & 540 & 2.157 & 542 & 0.242 \\
\hline & 507 & 0.891 & 508 & 2.214 & 515 & 0.234 \\
\hline & & & & & 413 & 0.559 \\
\hline & & & & & 305 & 1.173 \\
\hline \multirow[t]{6}{*}{ Acetone } & 664 & 0.825 & 663 & 0.533 & 661 & 1.011 \\
\hline & 606 & 0.213 & 605 & 0.157 & & \\
\hline & 540 & 0.328 & 534 & 0.224 & & \\
\hline & & & 504 & 0.27 & & \\
\hline & & & 409 & 1.945 & & \\
\hline & & & 339 & 3.457 & & \\
\hline
\end{tabular}

Note: $\lambda$ max-Wavelength of maximum absorption; ABS-Absorbance

\section{FT-IR spectroscopic analysis}

The FT-IR spectrum was used to identify the functional group of the active components with reference to the peak values in the region of infrared radiation. The analytical evaluation of the FT-IR spectrum in terms of functional groups corresponding to absorption of certain frequencies of $P$. wightii exhibited the spectral features. It also revealed significant differences in band position and absorbance intensities.

The comparative FT-IR spectrum showed an apparent change in relative intensity of the bands. FT-IR peak values for the three different parts of $P$. wightii were displayed with varied frequency 
ranged and the functional groups were obtained from absorption spectra in table 2 .

\section{FT-IR analysis of Pouzolzia wightii leaves}

The FT-IR peak values for five different extracts of $P$. wightii leaves were displayed in table 2; fig. 1-5. The strong and medium band with $\mathrm{C}-\mathrm{O}$ stretch, $\mathrm{C}-\mathrm{C}$-stretch (in ring) and-C=C-stretching vibration band corresponding to alcohols, carboxylic acids, esters, ethers, aromatics and alkenes showed their occurrence in all the five extracts viz., petroleum ether $\left(1166.29 \mathrm{ss} \mathrm{cm}^{-1}, 1410.84 \mathrm{~cm}^{-1} \mathrm{~cm}^{-1}\right.$ and $1658.15(\mathrm{~m})$ $\left.\mathrm{cm}^{-1}\right)$, acetone $\left(1036.43 \mathrm{ss}_{\mathrm{s})} \mathrm{cm}^{-1}, 1443.66(\mathrm{~m}) \mathrm{cm}^{-1}, 1448.37(\mathrm{~m}) \mathrm{cm}^{-1}\right.$ and $\left.1659.57(\mathrm{~m}) \mathrm{cm}^{-1}\right)$, chloroform $\left(1037.36_{(\mathrm{s})} \mathrm{cm}^{-1}, 1443.27_{(\mathrm{m})} \mathrm{cm}^{-1}\right.$ and $\left.1659.17(\mathrm{~m}) \mathrm{cm}^{-1}\right)$, ethanol $\left(1055.80 \mathrm{ss}_{\mathrm{sm}} \mathrm{cm}^{-1}, 1443.66(\mathrm{~m}) \mathrm{cm}^{-1}, 1659.26\right.$ (m) $\left.\mathrm{cm}^{-1}\right)$ and ethyl acetate $\left(1074.23 \mathrm{ss}^{\mathrm{cm}} \mathrm{cm}^{-1}, 1448.63\right.$ (m) $\mathrm{cm}^{-1}$ and $\left.1659.13_{(\mathrm{m})} \mathrm{cm}^{-1}\right)$ of $P$. wightii leaves respectively. The peak values at 1629.41, 1628.88, 1628.73 and 1628.09 (m) $\mathrm{cm}^{-1}$ respectively) matching to $\mathrm{N}-\mathrm{H}$ bend which represents the presence of Tamines in four different extracts of $P$. wightii leaves viz., petroleum ether, acetone, ethyl acetate and ethanol. Nitro compounds of medium intensity with $\mathrm{N}-\mathrm{O}$ symmetrical stretching was observed in acetone

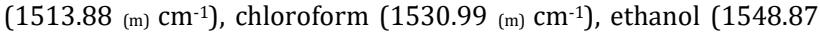
(m) $\left.\mathrm{cm}^{-1}\right)$ and ethyl acetate $\left(1530.86(\mathrm{~m}) \mathrm{cm}^{-1}\right)$ extracts $P$. wightii leaves. Two strong and two medium peaks obtained with $=\mathrm{C}-\mathrm{H}$ bend, $\mathrm{C}=\mathrm{O}$ stretch, $\mathrm{C}-\mathrm{H}$ stretch showed the presence of alkenes, $\alpha, \beta$ unsaturated aldehydes, ketones and alkanes in petroleum ether
(974.1 (s) $\mathrm{cm}^{-1} 8,1677.23$ (s) $\mathrm{cm}^{-1}$ and $2918.58_{(\mathrm{m})} \mathrm{cm}^{-1}$ ), ethyl acetate $\left(974.55_{(\mathrm{s})} \mathrm{cm}^{-1}, 1709.64(\mathrm{~s}) \mathrm{cm}^{-1}\right.$ and $\left.2918.19_{(\mathrm{m})} \mathrm{cm}^{-1}\right)$ and ethanolic (975.6(s) $\mathrm{cm}^{-15}, 1708.89$ (s) $\mathrm{cm}^{-1}$ and $2853.74_{(\mathrm{m})} \mathrm{cm}^{-1}$ ) extracts of $P$. wightii. The frequency 720.27 and $719.90(\mathrm{~m}) \mathrm{cm}^{-1}$ with strong and broad vibrations observed in petroleum ether and acetone extracts of $P$. wightii depicted the presence of alkanes. The band at 2850.83 and $2850.82(\mathrm{~m}) \mathrm{cm}^{-1}$ which was attributed to $\mathrm{O}-\mathrm{H}$ stretch revealed the presence of carboxylic acids in acetone and chloroform extracts of $P$. wightii. The functional group's alkyl halides and $12^{\circ}$ amines with the medium, strong and broad band corresponding to $\mathrm{C}-\mathrm{Br}$ stretch and $\mathrm{N}-\mathrm{H}$ wag at $690-515(\mathrm{~m}) \mathrm{cm}^{-1}$ and $910-665(\mathrm{~s}, \mathrm{~b}) \mathrm{cm}^{-1}$ peak values were present only in ethanolic extracts (669.32 and 900.07) of $P$. wightii.

Acetone extracts of $P$. wightii leaves showed the presence of functional groups viz., aromatics, 1,2 amines, amides corresponding to $\mathrm{C}-\mathrm{H}$ "oop" and $\mathrm{N}-\mathrm{H}$ stretch at peak values $833.48 \mathrm{ss}_{\mathrm{(s}} \mathrm{cm}^{-1}$ and $3357.61 \mathrm{~m}_{(\mathrm{m})} \mathrm{cm}^{-1}$ with strong and medium intensity band. The medium and strong intensity band occur at 836.07 (m) $\mathrm{cm}^{-1}$ and 1722.54 (s) $\mathrm{cm}^{-1}$ peak values were corresponding to $\mathrm{C}-\mathrm{Cl}$ and $\mathrm{C}=0$ stretching indicated the presence of alkyl halides, esters and saturated aliphatics only in ethyl acetate extract of $P$. wightii. The functional group's alkyl halides, aldehydes, saturated aliphatics were located at $1162.05(\mathrm{~m}) \mathrm{cm}^{-1}$ and 1722.87 (s) $^{\mathrm{cm}^{-1}}$ peak values corresponding to $\mathrm{C}-\mathrm{H}$ wag $\left(-\mathrm{CH}_{2} \mathrm{X}\right)$ and $\mathrm{C}=0$ stretch which were present only in chloroform extracts of $P$. wightii leaves. In petroleum ether extracts of $P$. wightii the medium band at $1168.45(\mathrm{~m}) \mathrm{cm}^{-1}$ corresponding to $\mathrm{C}-\mathrm{N}$ stretch indicated the presence of aliphatic amines.

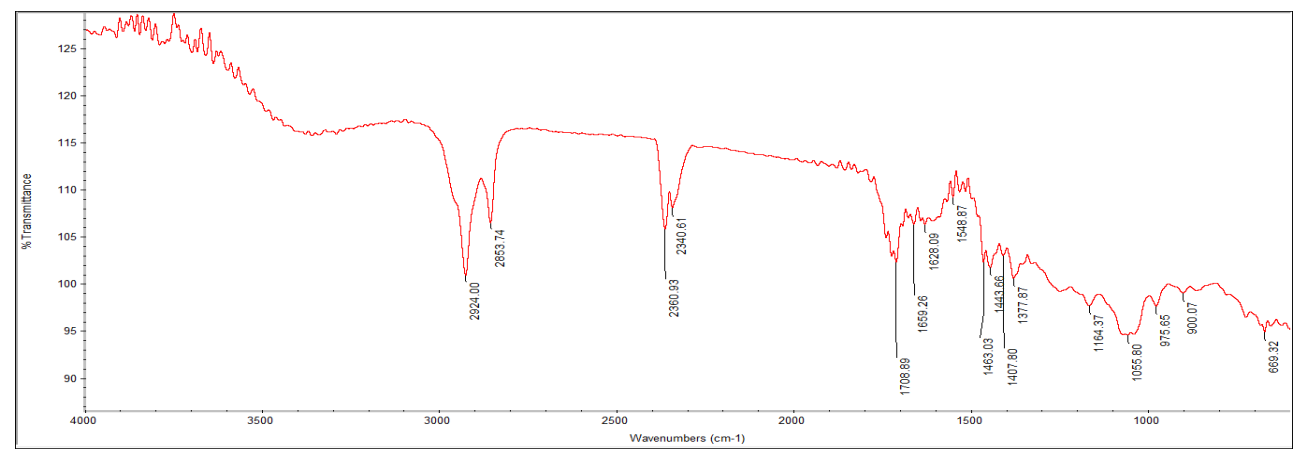

Fig. 1: FT-IR analysis of $P$. wightii leaves ethanolic extract

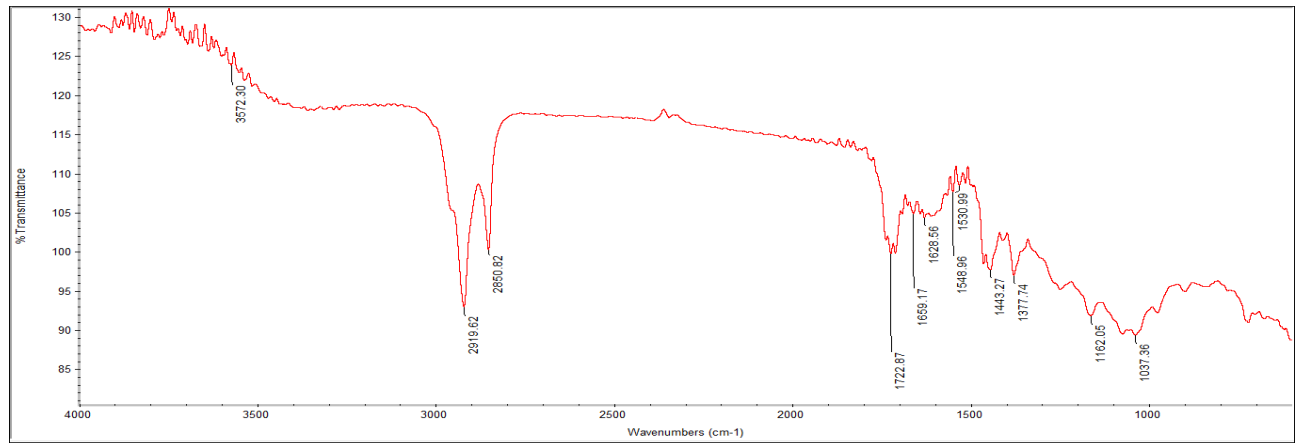

Fig. 2: FT-IR analysis of $P$. wightii leaves chloroform

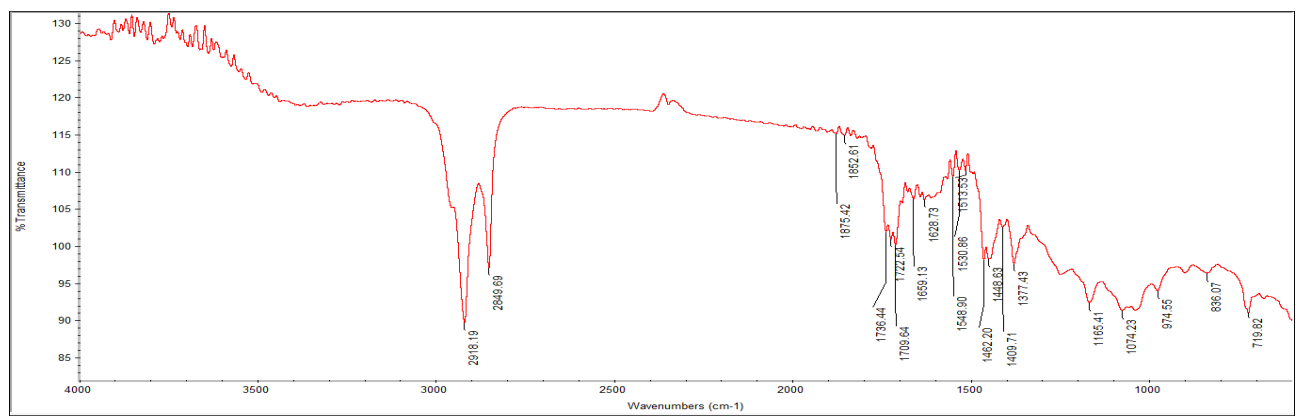

Fig. 3: FT-IR analysis of $P$. wightii leaves ethyl acetate extract 


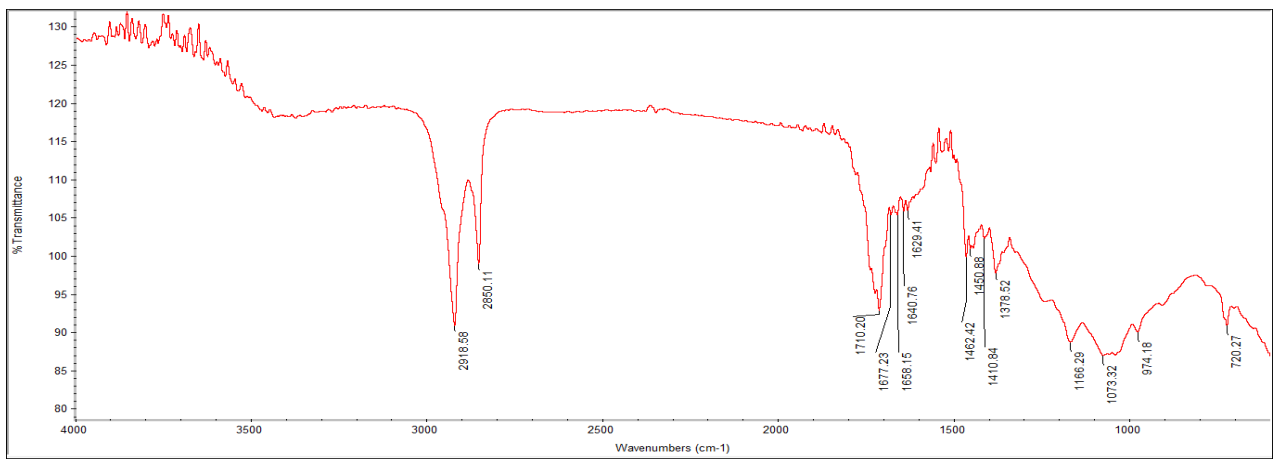

Fig. 4: FT-IR analysis of $P$. wightii leaves petroleum ether extract

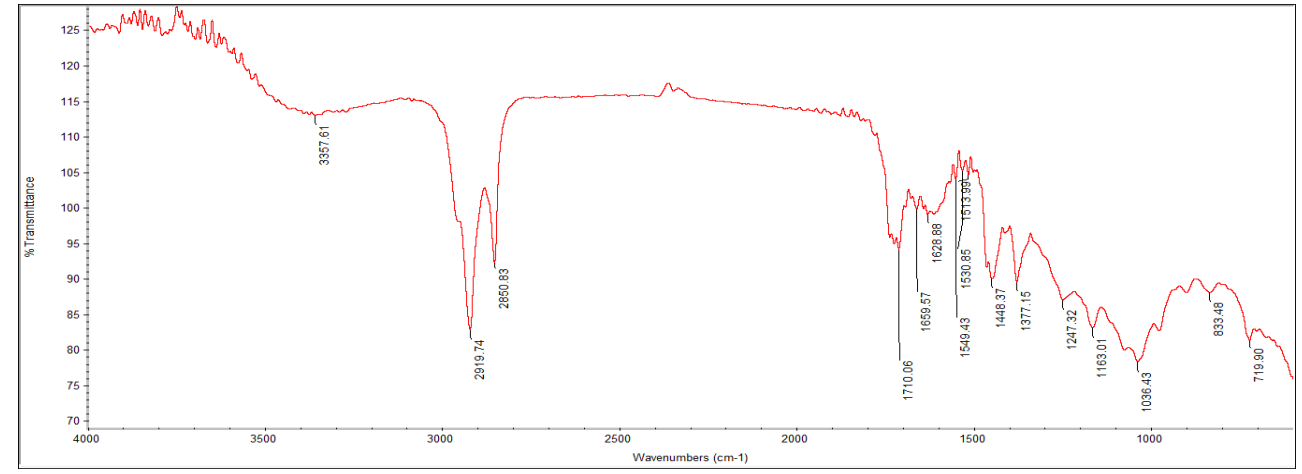

Fig. 5: FT-IR analysis of $P$. wightii leaves acetone

\section{FT-IR analysis of Pouzolzia wightii stem}

The medium intensity regions which were assigned due to $\mathrm{C}-\mathrm{N}$ stretch and $\mathrm{N}-\mathrm{H}$ bend vibration of aliphatic amines and 1 amines were observed in all the five different extracts viz., petroleum ether (1168.45 and $\left.1640.51(\mathrm{~m}) \mathrm{cm}^{-1}\right)$, acetone 1029.34 and $1601.21(\mathrm{~m}) \mathrm{cm}$ $\left.{ }^{1}\right)$, chloroform (1029.74 and $\left.1630.00 \mathrm{(m)}^{\mathrm{cm}} \mathrm{cm}^{-1}\right)$, ethanol (1028.58 and $\left.1600.58 \mathrm{(m}^{\mathrm{cm}} \mathrm{cm}^{-1}\right)$ and ethyl acetate (1031.02 and $\left.1601.00(\mathrm{~m}) \mathrm{cm}^{-1}\right)$ extracts of $P$. wightii (table 2; fig. 6-10). The functional groups alkanes with $\mathrm{C}-\mathrm{H}$ bend and carboxylic acid corresponding to $\mathrm{O}-\mathrm{H}$ stretch with medium intensity bands were found in four different extracts viz., petroleum ether (1462.48 and 2848.50 (m) $\left.\mathrm{cm}^{-1}\right)$, acetone (1463.17 and $2849.02 \mathrm{(m)}^{-1}$ ), chloroform (1462.68 and $\left.2848.58(\mathrm{~m}) \mathrm{cm}^{-1}\right)$ and ethyl acetate $\left(1463.21\right.$ and $\left.2848.61(\mathrm{~m}) \mathrm{cm}^{-1}\right)$ extracts of $P$. wightii (table 2; fig. 6-10). Nitro compounds corresponding to $\mathrm{N}-\mathrm{O}$ symmetric stretching with medium intensity band which showed the presence in acetone $\left(1513.88_{(\mathrm{m})} \mathrm{cm}^{-1}\right)$, chloroform $\left(1513.28_{(\mathrm{m}) ~ \mathrm{~cm}^{-1}}\right)$, ethyl acetate $\left(1513.86_{(\mathrm{m})} \mathrm{cm}^{-1}\right)$ and ethanolic $\left(1514.53_{(\mathrm{m})} \mathrm{cm}^{-1}\right)$ extracts of $P$. wightii (table 2; fig. 6-10). Petroleum ether, acetone, ethanol and ethyl acetate extracts of $P$. wightii showed the presence of $\alpha, \beta$ unsaturated aldehydes, ketones matching to C-O stretch with the strong band at 1709.61, 1709.12,
1708.89 and 1709.64 (s) $\mathrm{cm}^{-1}$ respectively (table 2; fig. 6-10). Alkyl halides were found to be present with C-Cl stretch at 719.67, 719.40 and 719.67 (m) $\mathrm{cm}^{-1}$ respectively with medium intensity band represents its presence in petroleum ether, chloroform and ethyl acetate extracts $P$. wightii. The strong peak values intensity with $\mathrm{C}-\mathrm{O}$ stretching were determined the presence of alcohols, carboxylic

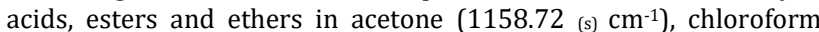
$\left(1162.67 \mathrm{ss}_{(\mathrm{s})} \mathrm{cm}^{-1}\right)$ and ethyl acetate $\left(1161.34{ }_{(\mathrm{s})} \mathrm{cm}^{-1}\right)$ extracts of $P$. wightii stem. The peak values at 1443.26, 1443.66 and $1448.63(\mathrm{~m})$ $\mathrm{cm}^{-1}$ respectively present in acetone, ethanol and ethyl acetate extracts of the stem with medium intensity band corresponding to CC stretch (in the ring) showed the presence of aromatics. The functional group's esters and saturated aliphatic with strong intensity band corresponding to $\mathrm{C}=0$ stretch were present in petroleum ether $\left(1736.04{ }_{(\mathrm{s})} \mathrm{cm}^{-1}\right)$ and ethyl acetate $\left(1722.54{ }_{(\mathrm{s})} \mathrm{cm}\right.$ 1) extracts of $P$. wightii stem. Alkenes at $1659.13(\mathrm{~m}) \mathrm{cm}^{-1}$ with medium intensity band corresponding to- $\mathrm{C}=\mathrm{C}$-stretch were found only in ethyl acetate extracts of $P$. wightii stem.

The functional group alkane corresponding to $\mathrm{C}-\mathrm{H}$ stretch with the medium band at $2853.74(\mathrm{~m}) \mathrm{cm}^{-1}$ peak value represents its occurrence only in ethanolic extracts $P$. wightii stem (table 2; fig. 6-10).

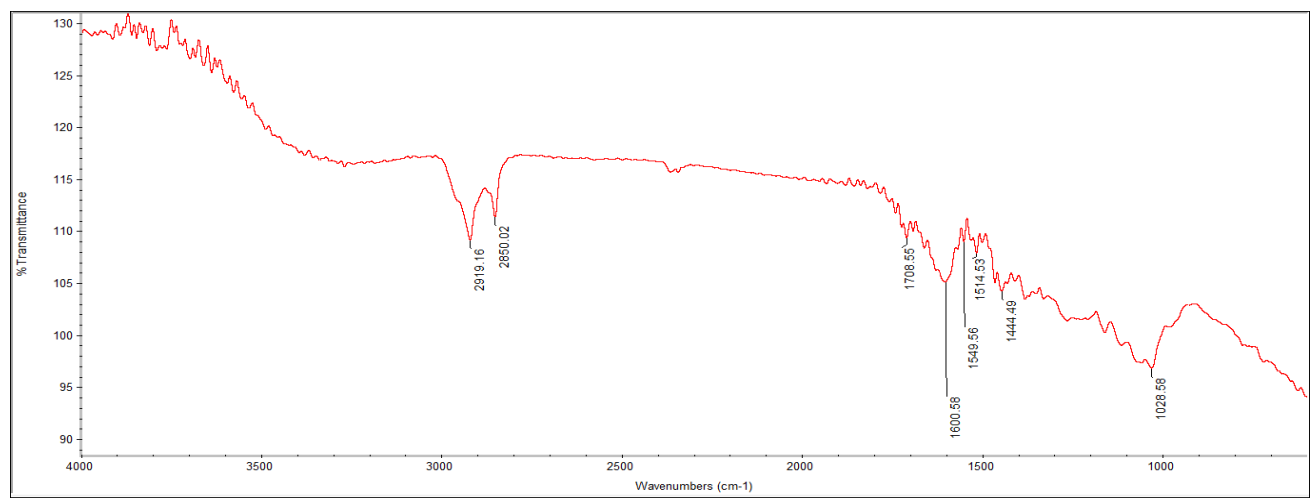

Fig. 6: FT-IR analysis of $P$. wightii stems ethanolic extract 


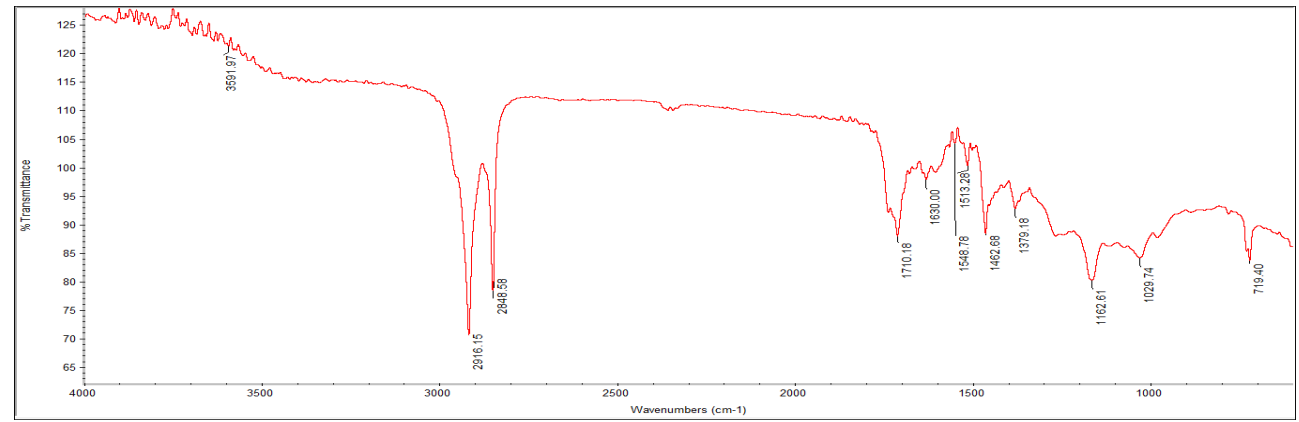

Fig. 7: FT-IR analysis of $\boldsymbol{P}$. wightii stem chloroform extract

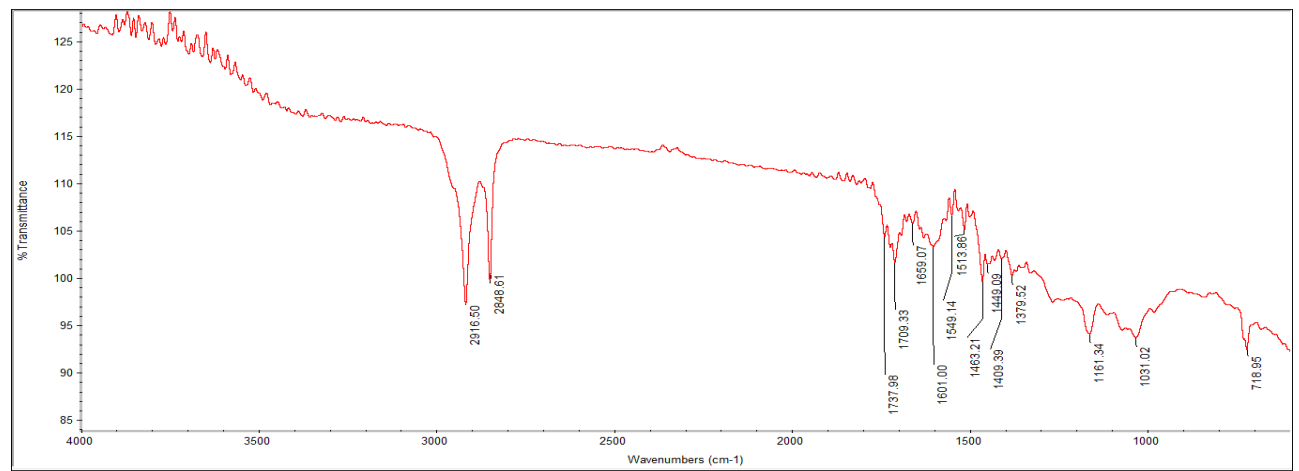

Fig. 8: FT-IR analysis of $P$. wightii stem ethyl acetate extract

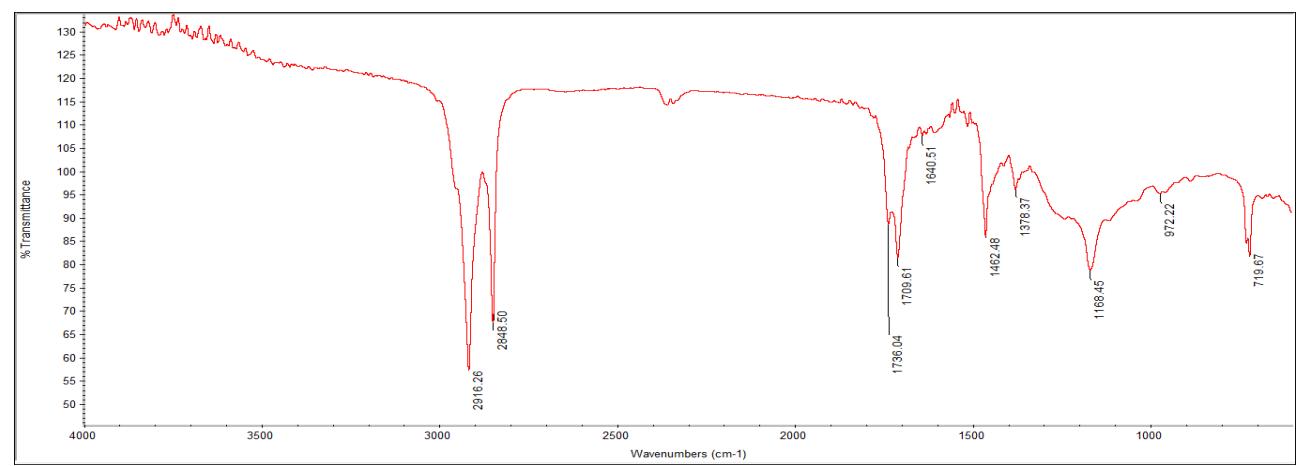

Fig. 9: FT-IR analysis of $P$. wightii stem petroleum ether extract

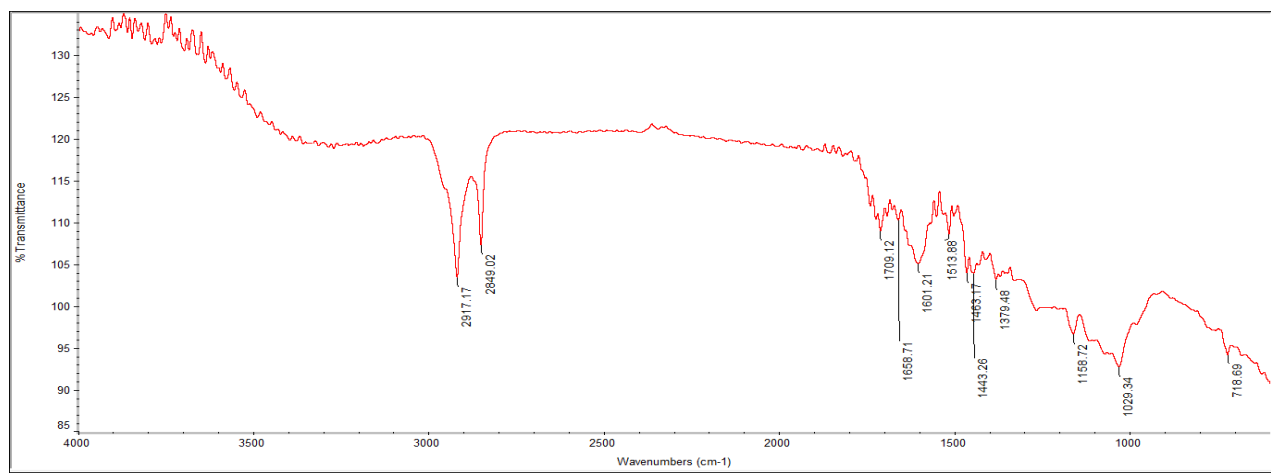

Fig. 10: FT-IR analysis of $P$. wightii stem acetone extract

\section{FT-IR analysis of Pouzolzia wightii root}

The presence of aliphatic amines with $\mathrm{C}-\mathrm{N}$ stretch, nitro compounds with N-O symmetric stretch, 1amines with $\mathrm{N}-\mathrm{H}$ bend and carboxylic acids with $\mathrm{O}-\mathrm{H}$ stretch respectively in all the five different extracts viz., petroleum ether (1034.91, 1513.55, 1630.67 and 2848.65), acetone $(1032.04,1514.25,1601.82$ and 2849.45), chloroform (1029.16, 1513.85, 1630.32 and 2848.70), ethanol (1056.54, 
$1515.98,1608.11$ and 2851.98$)$ and ethyl acetate $(1029.93,1513.51$, 1658.06 and 2848.62) extracts of $P$. wightii root (table 3; fig. 11-15). Alkyl halides with C-Cl stretch at 827.77, 775.81 and $834.46(\mathrm{~m}) \mathrm{cm}$ ${ }^{1}$ respectively with a band of medium intensity occurs in petroleum ether, ethanol and ethyl acetate extract $P$. wightii root (table 3, fig. 11-15). The functional group aromatic amines with the strong band at the peak values of $1266.88,1266.11$ and 1265.11 (s) $\mathrm{cm}$ ${ }^{1}$ respectively due to $\mathrm{C}-\mathrm{N}$ stretch showed their existence in petroleum ether, chloroform and ethyl acetate extract $P$. wightii root (table 3, fig. 11-15). The medium band intensity at $1462.52,1462.75$ and $1462.47(\mathrm{~m}) \mathrm{cm}^{-1}$ with C-H-bend determined the presence of alkanes in petroleum ether, chloroform and ethyl acetate extracts of $P$. wightii (table 3 , fig. 11-15). The strong band related to $\mathrm{C}=0$ stretching vibration indicated the existence of $\alpha, \beta$-unsaturated aldehydes, ketones in petroleum ether $\left(1709.67\right.$ (s) $\left.\mathrm{cm}^{-1}\right)$, acetone $\left(1708.99{ }_{(\mathrm{s})} \mathrm{cm}^{-1}\right)$ and ethanolic $\left(1768.35 \mathrm{ss}^{\mathrm{c}} \mathrm{cm}^{-1}\right)$ extracts of $P$. wightii root (table 3; fig. 11-15). The vibration of $\mathrm{C}-\mathrm{Br}$ stretch, $\mathrm{CH}$ 'oop' and =C-H bend showed the existence of alkyl halides, aromatics and alkenes in petroleum ether $\left(668.30(\mathrm{~m}) \mathrm{cm}^{-1}, 719.21(\mathrm{~s}) \mathrm{cm}^{-1}\right.$ and $\left.981.68{ }_{(\mathrm{s})} \mathrm{cm}^{-1}\right)$ and ethyl acetate $\left(668.79(\mathrm{~m}) \mathrm{cm}^{-1}, 719.09(\mathrm{~s}) \mathrm{cm}^{-1}\right.$ and $981.21_{(\mathrm{s})} \mathrm{cm}^{-1}$ ) extracts of $P$. wightii. An aromatics absorbed at the region 1442.59 and $1442.52(\mathrm{~m}) \mathrm{cm}^{-1}$ corresponding to C-C stretch (in the ring) revealed the presence in acetone and ethanolic extracts of $P$. wightii root. The strong intensity band occurring at 1739.91 and 1736.41 (s) $\mathrm{cm}^{-1}$ determined the presence of esters, saturated, aliphatic corresponding to $\mathrm{C}=\mathrm{O}$ stretching in ethanolic and ethyl acetate extracts of $P$. wightii root. The functional group 1, Zamines, amides with medium intensity band due to N-H stretch at 3284.12 and $3268.46(\mathrm{~m}) \mathrm{cm}^{-1}$ was present in chloroform and ethanolic extracts of $P$. wightii root. Alkanes with strong and broad intensity band due to $\mathrm{C}-\mathrm{H}$ rock, alkane with medium intensity band correspond to C-H stretch and alcohol, phenols with strong and sharp intensity band related to $\mathrm{O}-\mathrm{H}$ stretch free hydroxyl at peak values $718.71(\mathrm{~m}) \mathrm{cm}^{-1}, 2916.26(\mathrm{~m}) \mathrm{cm}^{-1}$ and $3633.45(\mathrm{~s}, \mathrm{sh}) \mathrm{cm}^{-1}$ were found only in chloroform extracts of $P$. wightii root.

The medium intensity band at 1658.06 (m) which was the representative for the presence of alkenes corresponding to- $\mathrm{C}=\mathrm{C}$ stretch occurred in ethyl acetate extracts of $P$. wightii root. The peak value 3485.86 (s,b) $\mathrm{cm}^{-1}$ with strong and broadband intensity corresponding to $\mathrm{O}-\mathrm{H}$ stretch bonded represents the presence of alcohol, phenols in ethanolic extracts of $P$. wightii (table 3, fig. 11-15).

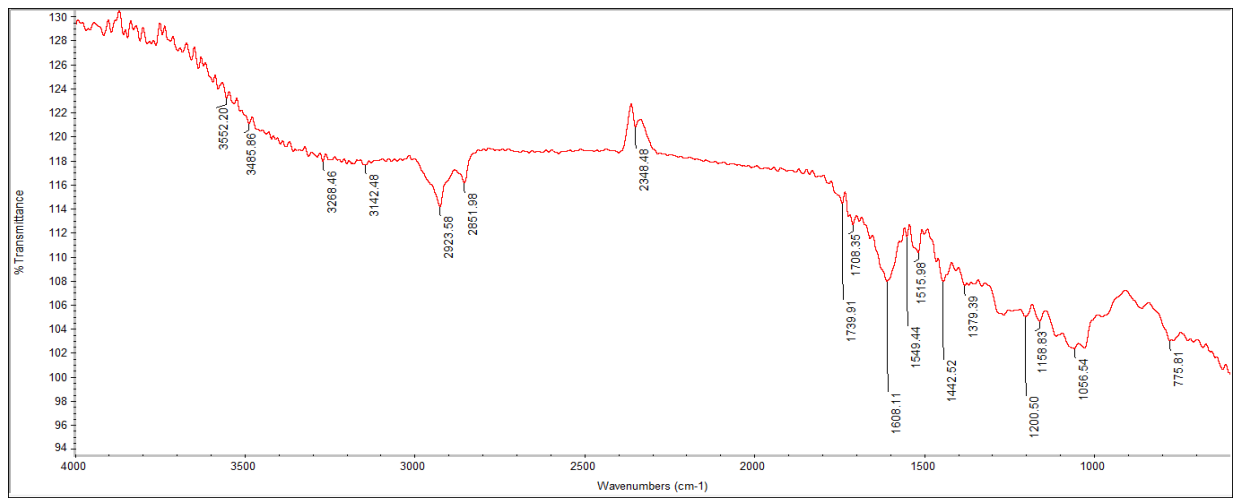

Fig. 11: FT-IR analysis of $P$. wightii root ethanol extract

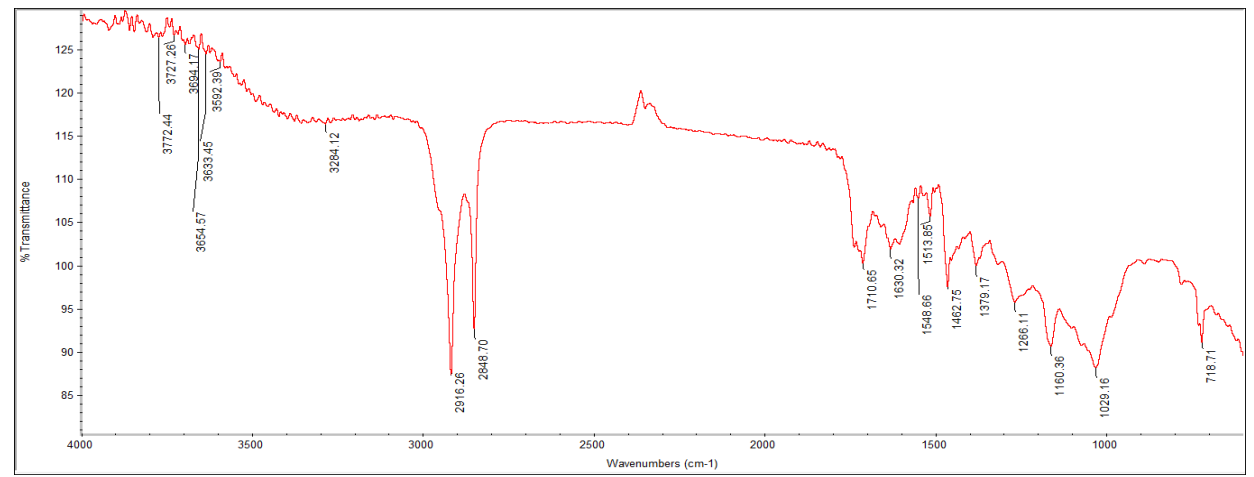

Fig. 12: FT-IR analysis of $P$. wightii root chloroform extract

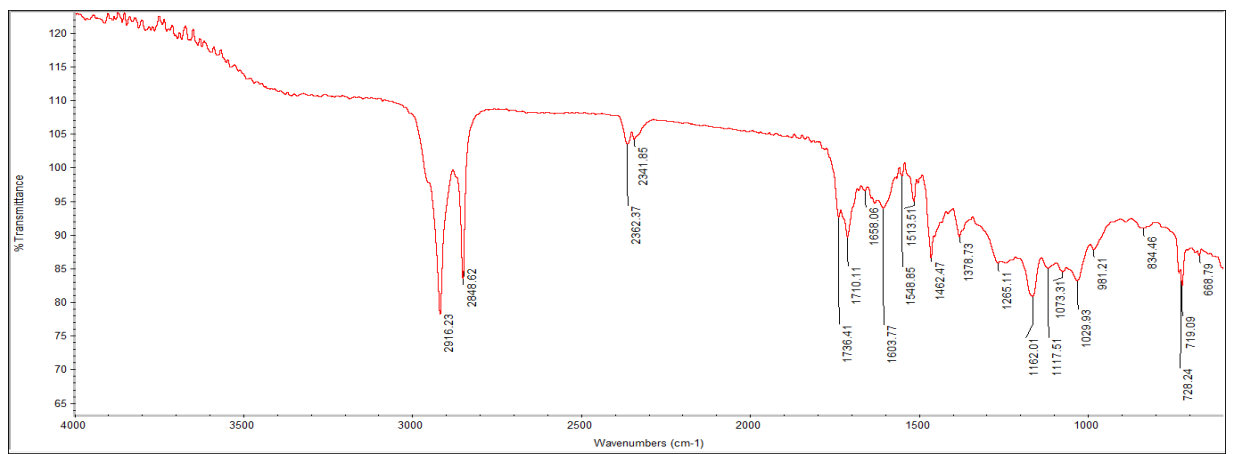

Fig. 13: FT-IR analysis of $P$. wightii root ethyl acetate extract 


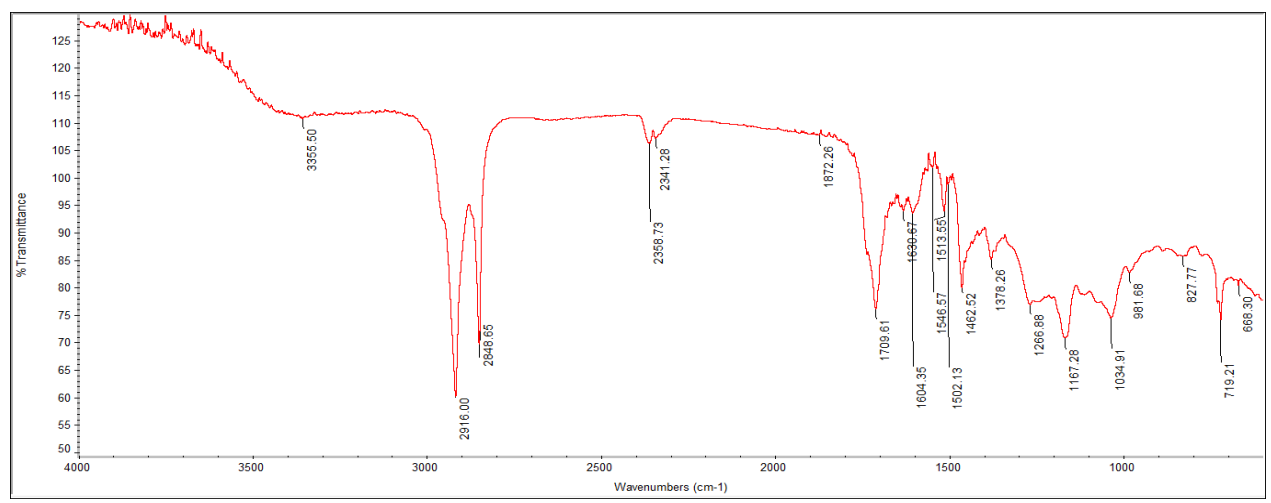

Fig. 14: FT-IR analysis of $P$. wightii root petroleum ether extract

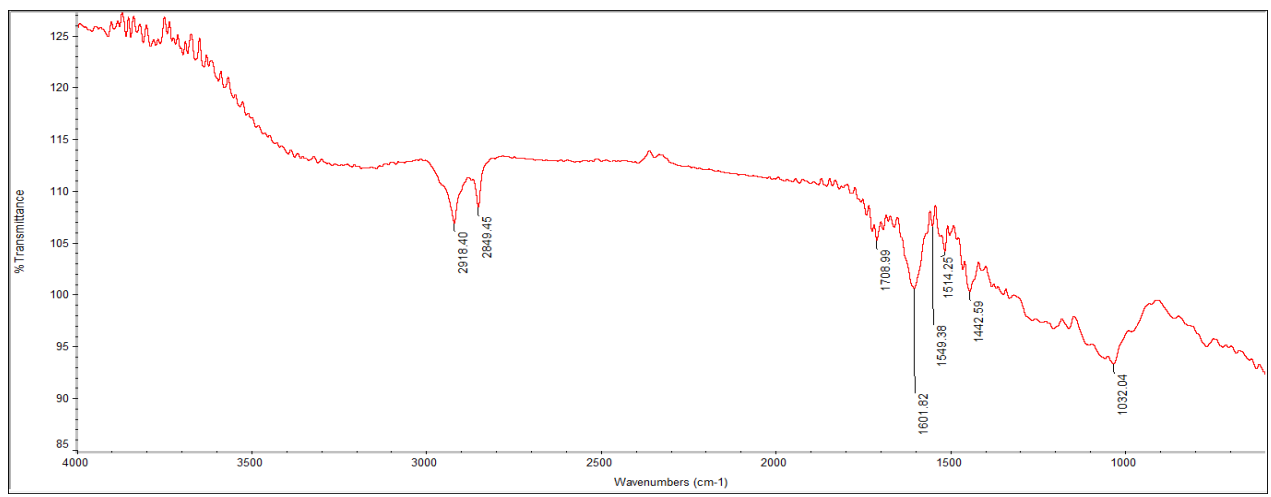

Fig. 15: FT-IR analysis of $P$. wightii root acetone extract

\section{DISCUSSION}

UV-Vis and FT-IR spectroscopic methods are proved to be a reliable and sensitive method for detection of biomolecular composition [10]. Plants contain a variety of chemical components which were used to prepare natural medicines [11].

Proper investigation of medicinal plants composition and their activity is very important to promote the therapeutic compounds [12]. The functional groups present in these chemical compounds of plants are usually identified by FT-IR. This technique is beneficial to elucidate the structure and gained importance to identify medicines in pharmacopoeia of many countries [13]. Thus, FT-IR spectroscopy technique has become one of the avenues for the identification of compounds.

The UV-Visible spectra results obtained in the methanolic extract of Meisotropis pellita leaves showed the absorption 0.085, 1.250, 2.605, 4.455 and 3.639 at 660, 340, 270, 235 and $210 \mathrm{~nm}$ [14]. They also reported the presence of phytochemicals flavonoids and alkaloids during qualitative analysis of the methanolic extract of $M$. pellita leaves supported by the spectroscopic studies showed the characteristic peaks obtained in UV-Visible region. In the present study also phytochemical flavonoids and alkaloids were found to be present during qualitative analysis of $P$. wightii leaves. The presence of these phytochemicals was also supported by the spectroscopic studies showing the characteristic peaks obtained in UV-Visible region. By using UV-Vis spectrum profile of methanolic extract of Drynaria quercifolia rhizome showed the peaks at 214 and $279 \mathrm{~nm}$ with the absorption of 2.60 and 0.92 [15].

The UV-Vis profile of acetone extract of Vitex altissima showed the peaks at 455,533 and $664 \mathrm{~nm}$ with the absorption of $2.571,0.659$ and 2.590 respectively. The ethanolic extract of $V$. altissima leaves showed the peaks at 422 and $664 \mathrm{~nm}$ with the absorption of 2.485 and 1.862 respectively. Petroleum ether extract of $V$ altissima leaves was observed the peaks at 410 and $669 \mathrm{~nm}$ with the absorption of 1.659 and 0.972 respectively. Chloroform extract of $V$. altissima leaves showed the peaks at 537, 609 and $668 \mathrm{~nm}$ with the absorption $1.180,0.912$ and 3.147 respectively [16]. In the present study acetone extract of $P$. wightii leaves showed the peaks at 644 $\mathrm{nm}$ with the absorption of 0.825 .

According to Sahu and Saxena [17] methanolic extract of Curcuma caesia rhizome showed three peaks at the wavelength 200 to $800 \mathrm{~nm}$. In $P$. wightii leaves (acetone, chloroform and ethyl acetate), stem (acetone) and root (petroleum ether) revealed the more number of peaks $(9,10$ and 15). Among the three parts, leaves were observed the highest absorbance 4.000 at $403 \mathrm{~nm}$ in the visible region. Hence, the extracts were subjected to UV-Vis analysis is used for the identification of chemical constituents present in $P$. wightii leaves, stem and root.

UV-Vis spectrum with absorption bands at 230-290 nm, 400-550 nm and $600-700 \mathrm{~nm} \mathrm{~nm}$ indicate the occurrence of flavonoids and its derivatives, terpenoids and chlorophyll in the crude extracts [18-20]. The occurrence of UV-Vis spectroscopic around 280-330 nm indicates the existence of phenolic derivatives, at $330 \mathrm{~nm}$ confirms the presence of flavonoids in the crude extracts $[20,21]$. In the present study, the chlorophyll occurrence was confirmed in all the studied extracts of $P$. wightii. The terpenoids existence also substantiated in the studied extracts of $P$. wightii except petroleum ether and ethanolic extracts of $P$. wightii stem and acetone extracts of $P$. wightii root.

The presence of phenols, alkanes, alcohol, alkyl halides, carboxyl acid and aromatic compounds in ethanolic extracts of Hybanthus enneaspermus was identified by FT-IR spectroscopy method [22]. FT-IR studies on the ethanolic extract of Albizia lebbeck leaves showed the presence of amide, alkynes, alkanes, carboxylic acids, alkenes, aromatics, aliphatic amines and alkyl halides compounds [23]. FT-IR analysis of Aerva lanata showed the presence of amino acids, organic hydrocarbons, halogens and amines [24]. IR spectrum of Caralluma nilagiriana extract showed the presence of $\mathrm{OH}$ group, phenol, alcohol, carboxylic acids, nitro compounds, esters and ethers group of compounds [20]. The FT-IR spectroscopic of Aerva lanata leaves validated the presence of alcohols, phenols, alkanes, carboxylic acids, aldehydes, alkenes, nitro compounds, alcohols, carboxylic acid, esters, ethers, aliphatic amines and alkyl halides 
compounds. The stem of Aerva lanata showed the presence of amide, alcohols, phenols, amines, alkanes, ketones, primary amines, nitro compounds, alcohols, carboxylic acids, esters, ethers, alkyl halides aliphatic amines. Roots of Aerva lanata also proved the presence of amines, amides, alkanes, aldehydes, ketones, esters, carboxylic acids, carbonyls, alkenes, primary amines, nitro compounds, aromatics, alcohols, esters, ethers, alkyl halides compounds [13].
The results of the present study also confirmed the occurrence of amide, alcohols, phenols, alkanes, carboxylic acids, aldehydes, ketones, alkenes, primary amines, aromatics, esters, ethers, alkyl halides and aliphatic amines compounds in $P$. wightii.

Many researchers used FT-IR analysis for identification, classification and identify the functional groups of closely related plants and other organisms [25-29].

Table 2: FT-IR peak values with functional groups of Pouzolzia wightii

\begin{tabular}{|c|c|c|c|c|c|c|c|c|c|c|c|c|c|c|c|c|c|}
\hline \multirow[t]{2}{*}{ Peak values } & \multirow[t]{2}{*}{ Bond } & \multirow[t]{2}{*}{ Functional group } & \multicolumn{5}{|c|}{ Leaves } & \multicolumn{5}{|c|}{ Stem } & \multicolumn{5}{|c|}{ Root } \\
\hline & & & $\mathbf{P}$ & $\mathbf{A}$ & $\mathbf{C}$ & ET & EA & $\mathbf{P}$ & $\mathbf{A}$ & $\mathbf{C}$ & ET & EA & $\mathbf{P}$ & $\mathbf{A}$ & $\mathbf{C}$ & ET & EA \\
\hline $690-515(\mathrm{~m})$ & C-Br strectch & Alkyl halides & - & - & - & + & - & - & - & - & - & - & + & - & - & - & + \\
\hline $900-675(s)$ & C-H "оop" & Aromatics & - & + & - & - & - & - & - & - & - & - & + & - & - & - & + \\
\hline $850-550(\mathrm{~m})$ & C-Cl stretch & Alkyl halides & - & - & - & - & + & + & - & + & - & + & + & - & - & + & + \\
\hline $725-720(\mathrm{~s}, \mathrm{~b})$ & C-H rock & Alkanes & + & + & - & - & - & - & - & - & - & - & - & - & + & - & - \\
\hline $910-665(\mathrm{~s}, \mathrm{~b})$ & N-H wag & $1^{\circ}, 2^{\circ}$ amines & - & - & - & + & - & - & - & - & - & - & - & - & - & - & - \\
\hline $1000-650(\mathrm{~s})$ & $=\mathrm{C}-\mathrm{H}$ bend & Alkenes & + & - & - & + & + & - & - & - & - & - & + & - & - & - & + \\
\hline $1320-1000(\mathrm{~s})$ & C-O stretch & $\begin{array}{l}\text { Alcohols, carboxylic } \\
\text { acids, esters, ethers }\end{array}$ & + & + & + & + & + & - & + & + & - & + & - & - & - & - & + \\
\hline $1250-1020(\mathrm{~m})$ & C-N stretch & Aliphatic amines & + & - & - & - & - & + & + & + & + & + & + & + & + & + & + \\
\hline $1300-1150(\mathrm{~m})$ & $\mathrm{C}-\mathrm{H}$ wag $\left(-\mathrm{CH}_{2} \mathrm{X}\right)$ & Alkyl halides & - & - & + & - & - & - & - & - & - & - & - & - & - & - & - \\
\hline $1335-1250(\mathrm{~s})$ & C-N stretch & Aromatic amines & - & - & - & - & - & - & - & - & - & - & + & - & + & - & + \\
\hline $1360-1290(\mathrm{~m})$ & $\begin{array}{l}\mathrm{N}-\mathrm{O} \text { symmetric } \\
\text { stretch }\end{array}$ & Nitro compounds & - & + & + & + & + & - & + & + & + & + & + & + & + & + & + \\
\hline $1500-1400(\mathrm{~m})$ & $\begin{array}{l}\text { C-C stretch (in- } \\
\text { ring) }\end{array}$ & Aromatics & + & + & + & + & + & - & + & - & + & + & - & + & - & + & - \\
\hline $1650-1580(\mathrm{~m})$ & N-H bend & $1^{\circ}$ amines & + & + & & + & + & + & + & + & + & + & + & + & + & + & + \\
\hline $1680-1640(\mathrm{~m})$ & $-\mathrm{C}=\mathrm{C}$-stretch & Alkenes & + & + & + & + & + & - & - & - & - & + & - & - & - & & + \\
\hline $1710-1665(\mathrm{~s})$ & $\mathrm{C}=0$ stretch & $\begin{array}{l}\alpha, \beta \text {-unsaturated } \\
\text { aldehydes,ketones }\end{array}$ & + & - & - & + & + & + & + & - & + & + & + & + & - & + & - \\
\hline $1740-1720(\mathrm{~s})$ & $\mathrm{C}=0$ stretch & $\begin{array}{l}\text { Aldehydes, } \\
\text { saturated aliphatic }\end{array}$ & - & - & + & - & - & - & - & - & - & - & - & - & - & - & - \\
\hline $1750-1735(\mathrm{~s})$ & $\mathrm{C}=0$ stretch & $\begin{array}{l}\text { Esters, saturated } \\
\text { aliphatic }\end{array}$ & - & - & - & - & + & + & - & - & - & + & - & - & - & + & + \\
\hline $3300-2500(\mathrm{~m})$ & O-H stretch & Carboxylic acids & - & + & + & - & - & + & + & + & - & + & + & + & + & + & + \\
\hline $3000-2850(\mathrm{~m})$ & C-H stretch & Alkanes & + & - & - & + & + & - & - & - & + & - & - & - & + & - & - \\
\hline $\begin{array}{l}3500- \\
3200(\mathrm{~s}, \mathrm{~b})\end{array}$ & $\begin{array}{l}\mathrm{O}-\mathrm{H} \text { stretch,H- } \\
\text { bonded }\end{array}$ & alcohols, phenols & - & - & - & - & - & - & - & - & - & - & - & - & - & + & - \\
\hline $\begin{array}{l}3400-3250 \\
(\mathrm{~m})\end{array}$ & $\mathrm{N}-\mathrm{H}$ stretch & $\begin{array}{l}1^{\circ}, 2^{\circ} \text { amines, } \\
\text { amides }\end{array}$ & - & + & - & - & - & - & - & - & - & - & - & - & + & + & - \\
\hline $\begin{array}{l}3640- \\
3610(\mathrm{~s}, \mathrm{sh})\end{array}$ & $\begin{array}{l}\text { O-H stretch,free } \\
\text { hydroxyl }\end{array}$ & alcohols, phenols & - & - & - & - & - & - & - & - & - & - & - & - & + & - & - \\
\hline
\end{tabular}

Note: P-Petroleum ether; A-Acetone; C-Chloroform; ET-Ethanol; EA-Ethyl acetate+Presence; -Absence

In the present study also FT-IR analysis is used to reveal the functional groups of P. wightii and results of the analysis confirmed the existence of various functional groups. The similarity and variation in functional groups at different parts such as leaves, stem and root of P. wightii alos identified. In the present study, FT-IR spectrum was used to confirm the functional group's presence in five different extracts of studied $P$. wightii leaves, stem and roots.

The FT-IR spectrum confirmed the presence of alcohols, phenols, alkanes, alkynes, alkyl halides, aldehydes, carboxylic acids, aromatics, nitro compounds and amines in different extracts of Vitex altisssima leaves. Aromatics were absorbed at the region of 900-675 $\mathrm{cm}^{-1} \mathrm{in}$ acetone and ethanolic extracts of $P$. wightii leaves. Aromatics were also observed in acetone and ethyl acetate leaf extracts and also in acetone stem extracts. An ethanolic and chloroform extracts of $P$. wightii stem and root showed the presence of functional group alkane. In the crude extracts of $O$. stamineus, a sharp absorption peak at $1600-1760 \mathrm{~cm}^{-1}$ was observed and it indicated the $\mathrm{C}=0$ stretching vibration in carbonyl compounds [30].

The FT-IR spectrum of Cleome gynandra showed the presence of phenol ring and nitrosamine by the strong absorption bands at 1458 $\mathrm{cm}^{-1}$. The peak at $3419 \mathrm{~cm}^{-1}$ assigned to $\mathrm{O}-\mathrm{H}$ stretching vibrations was observed in Eichhornia crassipes. Ethanolic extracts of $P$. wightii root confirmed the presence of $\mathrm{O}-\mathrm{H}$ stretch. FT-IR analysis of dry methanolic extract of Punica granatum peel proved the presence of alkenes, aliphatic fluoro compounds, alcohols, ethers, carboxylic acids, esters, nitro compounds, alkanes, H-bonded H-X group, Hydrogen-bonded alcohols and phenols which shows major peaks values were found to be $671.23,688.59,707.88,754.17,802.39$, $875.68,921.97,1016.49,145.72,1226.73,1317.38,1338.60$ 2860.43, 2929.87, 3082.25, 3176.76, 3219.19, 3246.20, 3265.49 and 3334.92. Similarly, $P$. wightii leaves extracts viz., petroleum ether, acetone, chloroform, ethanol and ethyl acetate contains alcohols, carboxylic acids, esters and ethers. Nitro compounds were observed in all the extracts of $P$. wightii root and stem, except petroleum ether and also occurred in acetone, ethanol and ethyl acetate extracts of $P$. wightii leaves extracts. In addition to the previous observation, the current study exposed and supplemented the functional groups of $P$. wightii leaves, stem and root.

The present study used to find out the bioactive compounds which may be subjected to subsequent target isolation. The results of the present study revealed the spectroscopic profile for the medicinally important plant $P$. wightii. These profiles will be used as a pharmacognostic marker in the pharmaceutical industries. Further research will be needed for the isolation of active principles and structural characterization of isolated compound.

Contribution Details: Dr. M. Johnson is designed the study and contributed in the manuscript writing and discussion. Mrs. Syed Ali Fathima is executed and collected the data for writing. She collected 
the reviews and summarized the results. She also contributed in the writing of the manuscript.

\section{AUTHORS CONTRIBUTIONS}

All the author have contributed equally

\section{CONFLICT OF INTERESTS}

Declared none

\section{REFERENCES}

1. Ghani A. Medicinal plants of Bangladesh with chemical constituents and uses. $2^{\text {nd }}$ edition. Bangladesh: Asiatic Society of Bangladesh, Dhaka; 2003.

2. Ashis G. Herbal folk remedies of Bankura and Medinipur districts, West Bengal. Indian J Traditional Knowledge 2003;2:393-6.

3. Sakanaka S, Tachibana Y, Okada Y. Preparation and antioxidant properties of extracts of Japanese permimmon leaf tea (kakinocho-cha). Food Chem 2005;89:569-75.

4. Argal A, Pathak AK. CNS activity of Calotropis gigantean roots. J Ethnopharmacol 2006;106:142-5.

5. Parekh J, Chanda V. In vitro antimicrobial activity and phytochemical analysis of some Indian medicinal plants. Turkish J Biol 2007;31:53-8.

6. Ibrahim M, Hameed AJ, Jalbout A. Molecular spectroscopic study of river nile sediment in the greater cairo region. Appl Spectroscopy 2008;62:306-11.

7. Yang J, Yen HCE. Early salt stress effects on the changes in chemical composition in leaves of ice plant and Arabidopsis. A fourier transform infrared spectroscopy study. Plant Physiol 2002;130:1032-42.

8. Surewicz WK, Mantsch HH, Chapman D. Determination of protein secondary structure by fourier transform infrared spectroscopy: a critical assessment. Biochemistry 1993;32: 389-93.

9. Mistry BD. A Handbook of spectroscopic data. Jaipur, India: Oxford Book Company; 2009.

10. Kumar JK, Devi Prasad AG. Identification and comparison of biomolecules in medicinal plants of Tephrosia tinctoria and Atylosia albicans by using FT-IR. Romanian J Biophys 2011;21:63-71.

11. Thenmozhi M, Bhavya PK, Rajeswari S. Compound isolation using HPLC and FT-IR in Eclipta alba and Emilia sanchifolia. Int J Eng Technol 2011;3:292-8.

12. Nair R, Chanda S. Activity of some medicinal plants against the certain pathogenic bacterial strain. Indian J Pharmacol 2006;38:142-4.

13. Yamuna M, Gnanaraj WE, Johnson M. FT-IR spectroscopic studies on Aerva lanata (L.) Juss. Ex. Schult. Asian J Pharm Clin Res 2012;5:82-6.

14. Rani N, SharmaS, Mukta Sharma. Phytochemical Analysis of Meizotropis pellita by FT-IR and UV-Vis spectrophotometer. Indian J Sci Technol 2016;9:1-4.
15. Prasanna G, Anuradha R. Ultraviolet-visible and fourier transform-infrared spectroscopic studies on Drynaria quercifolia L. Rhizome Asian J Pharm Clin Res 2016;9:85-8.

16. Sahaya Sathish S, Janakiraman N, Johnson M. Phytochemical analysis of Vitex altissima L. using UV-Vis, FT-IR and GC-MS. Int J Pharm Sci Drug Res 2012;4:56-62.

17. Sahu R, Saxena J. Ultraviolet-visible and fourier transform infrared spectroscopic studies on non-conventional species of Curcuma. Indian J Adv Chem Sci 2014;2:300-2.

18. Mamta S, Jyoti S. Evaluation of phytoconstituents of Acorus calamus by FT-IR and UV-Vis spectroscopic analysis. Int J Biol Pharm Res 2012;3:498-501.

19. Neha S, Jyoti S. Phytochemical analysis of Bougainvillea glabra choisy by FT-IR and UV-Vis spectroscopic analysis. Int J Pharm Sci Rev Res 2013;2:196-8.

20. Renuka B, Sanjeev B, Ranganathan D. Evaluation of phytoconstituents of Caralluma nilagiriana by FT-IR and UV-Vis spectroscopic analysis. J Pharmacognosy Phytochem 2016;5:105-8.

21. Bunghez F, Socaciu C, Zăgrean F, Pop MR, Ranga F, Romanciuc F. Characterisation of an aromatic plant-based formula using UV-Vis spectroscopy, LC-ESI(+)QTOF-MS and HPLC-DAD analysis bulletin UASVM. Food Sci Technol 2013;70:16-24.

22. Anand T, Godula Krishnan. Phytochemical analysis of Hybanthus enneaspermus using UV, FT-IR and GC-MS. IOSR J Pharm 2012;2:520-4.

23. Bobby MDN, Wesely EG, Johnson M. FT-IR studies on the leaves of Albizia lebbeck benth. Int J Pharm Pharm Sci 2012;4:293-6.

24. Ragavendran P, Sophia D, Arul Raj C, Gopalakrishnan VK. Functional group analysis of a various extract of Aerva lanata (L.) by FT-IR spectrum. Pharmacologyonline 2011;1:358-64.

25. Helm D, Labischinski H, Schallehn G, Naumann D. Classification and identification of bacteria by fourier transform infrared spectroscopy. J Gen Microbiol 1991;137:69-79.

26. Kim SW, Ban SH, Chung H, Cho S, Chung HJ, Chol PS, et al. Taxonomic discrimination of flowering plants by multivariate analysis of fourier transform infrared spectroscopy data. Plant Cell Reports 2004;23:246-50.

27. Janakiraman N, Sahaya Sathish S, Johnson M. UV-Vis and FTIR spectroscopic studies on Peristrophe bicalyculata (Retz,) Nees. Asian J Pharm Clin Res 2011;4:125-9.

28. Janakiraman N, Johnson M. Functional groups of tree ferns (Cyathea) Using FT-IR: chemotaxonomic implications. Rom J Biophys 2015;25:131-41.

29. Johnson M, Petchiammal E. Phytochemical characterization of Sargassum swartzii (Turner) C. Agardh using thin-layer chromatography, Fourier transform infrared and highperformance liquid chromatography. J Med Herbs Ethnomed 2015;1:120-4.

30. Sim CO, Hamdan MR, Ismail Z, Ahmad MN. Assessment of herbal medicines by chemometrics-assisted Interpretation of FT-IR spectra. J Anal Chim Acta 2004;570:1-14. 